\title{
Communication of Global Aspects of Corporate Social Responsibility in the Circular Economy
}

\author{
Jaroslav Bednárik ${ }^{1, *}$, and Natália Augustínová ${ }^{1}$ \\ ${ }^{1}$ University of SS Cyril and Methodius in Trnava, Faculty of Mass Media Communication, \\ Department of Marketing Communication, Námestie J.Herdu 2, 91701 Trnava, Slovakia
}

\begin{abstract}
.
Research background: The essence of corporate social responsibility is not new, but its form has changed over the years, as has changed the view on whether it is possible and beneficial to put this idea into practice. CSR concerns economics, corporate management, business ethics, sociology, political science, environmental sciences and many other disciplines and is becoming increasingly popular among the general public. In this context, it is possible to look for connections and links to the circular economy. The circular economy is a sustainable development strategy that creates functional and healthy relationships between nature and human society. It perfectly closes material flows in long-term cycles.

Purpose of the article: The paper aims to point out the possibilities of linking CSR concerning the environmental pillar, with the processes of the circular economy in the global environment through a concrete example.

Methods: To achieve the set goal, published materials of domestic and foreign authors were examined. As part of the in-depth analysis, case studies of selected subjects were examined. Besides, a synthetic-analytical method and an inductive-deductive method were used.

Findings \& Value added: The expected result will provide a picture of the possibilities of connecting corporate social responsibility regarding the processes of the circular economy. The findings may lead to a more effective link between CSR and the circular economy.
\end{abstract}

Keywords: corporate social responsibility; circular economy; environmental pillar; global environment; sustainable development

JEL Classification: Q01, Q5

\footnotetext{
* Corresponding author: jaroslav.bednarik@ucm.sk
} 


\section{Introduction}

When we mention globalization, we consider it as one of the aspects with a significant impact on increasing the importance of corporate social responsibility. [1]

One should realize that in recent times, in developed countries, their production has focused less on industrial production and more on service delivery and information flow management. $[2,3]$ In this context, the issue of responsible business also comes to the forefront. [4] Corporate social responsibility brings a new perspective on the social role of the company, an awareness of the interrelationship between profitability, ethical and environmental standards of business. [5] The company is increasingly focused on environmental protection, local community development, ethical business and improving relationships with employees and partners. $[6,7]$

This process also includes the issue of the circular economy, the aim of which is to use as few resources as possible through more efficient procedures, elimination of waste generation, reuse, processing and recycling. [8-14] It focuses mainly on material cycles and uses energy from renewable sources. The durability design ensures that technical products last as long as necessary, are easy to maintain and have high value even when taken as second-hand ones. Disassembly focused design means that products and their components can be repaired, reprocessed and recycled as raw material for the next production process.

\section{Corporate social responsibility}

When defining corporate social responsibility and business, the voluntary nature of companies to go beyond the legislation and take proactive steps in these areas, in the implementation of which they cooperate with other entities, i.e., stakeholders interacting with the company and influence each other. $[15,16]$

Elibert and Parker argue that: "Probably the best way to understand social responsibility is to think of it as a 'good neighbourhood.' There are two stages to this concept. At first, it means prevent doing things that could damage the neighbourhood. The second stage is the voluntary commitment to help solve issues in the neighbourhood. " [17]

Among Slovak authors, we consider the most precise and accurate definition mentioned by Zorkóciová in her publication Corporate Identity II, and describes it as " $a$ business concept in which companies voluntarily incorporate social and environmental elements into their business and stakeholder relations. " [18]

Corporate social responsibility and entrepreneurship, therefore, is accepted by the people who are interested in the quality of life and the overall impact of business on society.

At the global level, the movement is currently run by the United Nations, which in 2000, under the direct leadership of Secretary-General Kofi Annan, announced the Global Compact. It is an international network of UN agencies, NGOs, business representatives and other international organizations (International Labor Organization, World Business Council for Sustainable Development). The initiative aims to promote the nine basic principles of corporate social responsibility. Another crucial international player succeeded in the formulation of fundamental principles and the promotion of this initiative is the Organization for Economic Co-operation and Development (OECD). Another critical international player supporting the corporate social responsibility movement is the European Union; since the early 1990s, it promoted cross-sectoral cooperation and an open market where all social groups and many other organizations can make a significant contribution to formulating, promoting and putting into practice the principles of corporate social responsibility. $[19,20]$ 


\section{Circular economy}

A one-way linear resource-product-waste process characterizes the regular (linear) economy, focused on maximizing social wealth and profit, which excessively consumes natural resources, produces an uncontrollable amount of waste with a negative impact on natural resources and the environment. The essence of the profit of the current "take-producethrow away" system is above all, the high consumption of non-renewable raw materials, which logically we cannot keep in the long run. If we add other negative factors, such as cheap labor from developing countries, population explosion, growing consumption and devastating human impact on the environment, we could consider this system to be unsustainable, from an economic, ecological and social point of view. [21, 22]

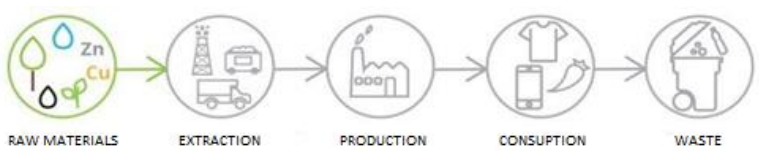

Fig. 1. Linear economics scheme Source: incien.sk

Opposed to the linear economy, the circular (closed) economy is a scientific conception of the model of sustainable development of the economy. [24] The circular economy is characterized by a closed-loop flow of material and energy, considering natural and human resources, science and technology. [24-26]

The priority of the circular economy is the saving and efficient use of limited natural resources, more efficient production of products while maintaining high efficiency and low resource consumption and low (or even zero) emissions. It includes the prevention and reduction of the production of waste and, subsequently, of pollutant sources up to recycling, when resources return to the economic cycle, which comes with increasingly urgent practical importance. $[27,28]$

The early concept of the circular economy dates back to 1960 when observing an increased interest in environmental protection and several ecologists, economists and other experts began to address this issue. The development of the knowledge and circular economy on an international scale has increased significantly since 1990. Germany, for example, introduced its concept of the circular economy in 1998. [29]
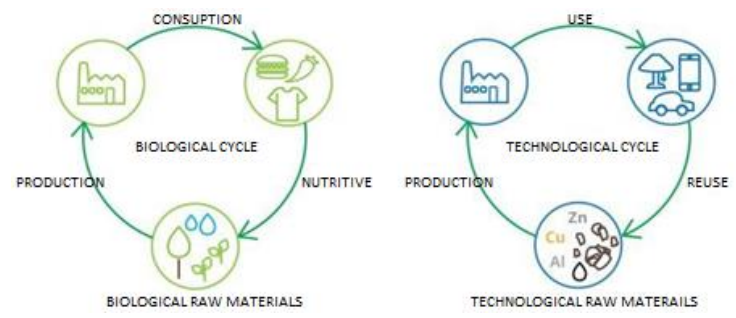

Fig. 2. Circular economy scheme

Source: incien.sk

The European Economic and Social Committee held a circular economy conference in Brussels on 9-10 March 2017. The circular economy package was adopted then, containing legislative proposals on waste stimulating Europe's transition to a circular economy that would strengthen overall competitiveness, support and sustainable economic growth and 
create new jobs. These legislative proposals on waste set clear targets for waste reduction and waste management.

The critical elements of this European Union proposal are:

- Recycling $65 \%$ of general waste by 2030

- Recycling of $75 \%$ of packaging waste by 2030

- Not allowed storage of mixed waste

- Promoting economic instruments to discourage waste storage

- Specific measures to promote reuse activities

- Incentives for producers to produce greener products and use alternative energy sources. [29]

\section{Materials and methods}

In the following part of our paper, a case study was run, where a selected business entity was examined using an in-depth analysis. This entity operates in the field of special medical technology. The analysis was focused on the method and effectiveness of communication of CSR principles in the processes of the circular economy in the external and internal environment in normal conditions and the event of a crisis. The analysis has been done based on a study of the company's internal materials and management statements.

\section{Results and discussion}

\subsection{Communication of Global Aspects of Corporate Social Responsibility in the Circular Economy - case study}

Effective communication of the positives brought by applying the principles of corporate social responsibility is one of the most critical opportunities for the company, supporting its relations with all stakeholders. Communication of corporate social responsibility should become part of the processes of strategic management while focusing mainly on the company itself, the media. [30]

Examples of the positive impact of communication could be as follows:

- Higher level of customer satisfaction and loyalty

- Improving the company's reputation

- More motivated and productive employees

- Better relations with the environment and public authorities [31]

It is necessary for the company to clearly define the specific goals, vision, target audience and the message it needs to communicate.

\subsection{Introduction of company GUTTA Slovakia s.r.o.}

GUTTA SLOVAKIA spol. s r.o. is a trading company founded in January 1997, focusing on the distribution, rental and servicing of special medical equipment and supplies. The company is registered as a trading company - no products are manufactured or developed here. The quality and tradition are also confirmed and proved by the fact that it represents and distributes the devices of the American company Hologic.

Currently, the company belongs to the leaders on the Slovak and Czech markets in densitometry and mammography. The pros are continually growing market share and the company's profits. In 2010, the company began distributing devices from another American company, Faxitron, and the Hungarian company, Mediso Medical Imaging Systems. In 2014, 
it added the distribution of special medical material from Vigeo, offering a wide range of biopsy material for various fields (radiology, urology, haematology, etc.). In 2015, it launched a special test from Agendia to detect breast cancer aggressiveness. The MammaPrint test result allows the specialists to determine the optimal treatment.

\subsection{Products of the company}

Distributed products of GUTTA Slovakia s.r.o. are:

- Imagine technique - mammography devices, intervention solutions, digital imaging of samples, densitometric devices, mini C-arm, nuclear medicine and X-ray devices

- Laboratory and gynaecological solutions - cervical health screening, non-gynaecological cytology, cytological devices, molecular devices, sexually transmitted infections, virology, microbial infectious diseases, perinatal risk assessment of preterm birth, gynaecological interventions and treatment, DNA microarray

- Medical material - haemostatics, closed collection system, hospital products

- Biopsy and ablation ABLATION - Hologic - vacuum biopsy with accessories, Vigeo biopsy guns, Vigeo - core cut biopsy, RF ablation, localization, drainage, ablation devices

\subsection{Business goals of the company}

GUTTA Slovakia s.r.o. is currently the market leader and therefore aims to maintain its market share. Nevertheless, with the growing competition, it is essential for the company to continually work on the market share and raise awareness of brand loyalty and the long-term strength, thanks to the quality of the products offered. The company would like to establish and improve cooperation with all existing and potential partners of these companies in Slovakia. The aim is to offer clients a comprehensive portfolio of services of the highest possible quality. Employees are regularly trained to respond to all client requests and provide them with adequate care.

\subsection{Crisis management and crisis communication in the company}

GUTTA Slovakia, s.r.o. has 19 permanent employees, supplemented by external employees, such as economic, accounting, business, IT, or marketing department, tax advisors, or service workers. The company decided to outsource these departments, as they are not a vital driving force.

Based on the results from the Finstat.sk website, GUTTA Slovakia reached revenues of 6.6 mil. $€$ in 2014 , that decreased to almost half less a year later. However, the company's profits increased by a small amount. Subsequently, in 2016, the company decreased even more, but after 2 years, it reached success again.

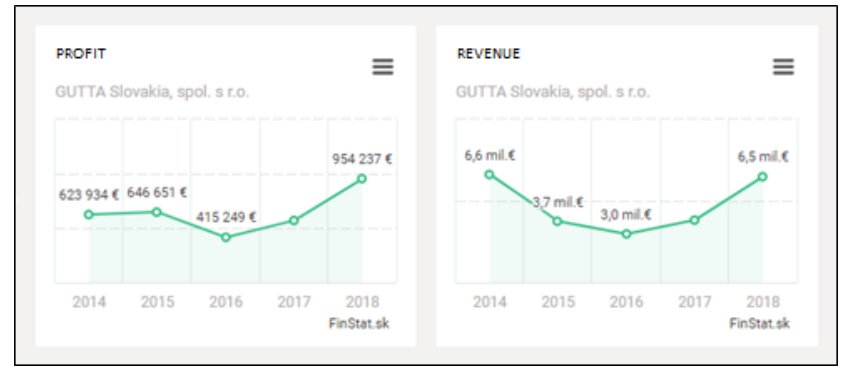

Fig. 3. Profit and revenues of the company

Source: Finstat.sk, 2016 
Although the company's profits are currently growing, the company is well prepared for all the possible crises.

The company has created one-level crisis management: "Executives of crisis management are in the functional positions of top management of the company. They are, therefore, performers of conceptual and operational activities. Business specialists in top line and staff positions provide crisis management tasks. One-level crisis management is typical for small and medium-sized enterprises. The skills needed are conceptual, technical and also the skill of working with people." [32]

The situation is primarily monitored by the company's CEO, together with the economist plan the main steps to be taken. Executives who know how to provide more accurate information are also always available. Depending on the size of the crisis and the severity of the situation, they have funds set aside for a specialized external company prepared for each type of crisis and know best what measures are needed and necessary. So far, it was not needed.

Overall, the company is dependent on the health sector of the Slovak Republic and thus also on the development of the financial situation and subsidies from the state budget. Therefore, to put it in a nutshell, if the health sector does not have financial support due to a bad financial situation, no one will buy the company's products. [33] On the other hand, healthcare is a primary sector subsidized by the state and European Union resources, so it does not worry about the future.

According to the owner of the company: "The company has probably been fortunate so far, or it just has a good strategy, but we have never encountered a serious crisis. Even our second company made a profit during the recession." The company's motto is:

\section{And what is the secret of the company's success? SATISFIED EMPLOYEE}

The most significant value for the company is the people and therefore, in times of crisis, they do not take steps common for other companies, such as reducing the number of employees, cutting down positions, or even reducing salaries. On the contrary, the company has set aside money for the future for at least 2 years in order to maintain the operation or salaries of employees, even in a crisis. Employees are the leading force moving the company forward, and when they are satisfied, they stay in the company for a long time and their performance does not drop into red numbers as should be suspected.

\subsection{Circular economy in the company}

GUTTA Slovakia has adopted the concept of corporate social responsibility. The main goal of such behaviour is not only to achieve the maximum profit of the company, but also goals based on the internal and external environment of the company. "corporate social responsibility act with respect for the needs of their internal and external environment. They provide an improvement that goes beyond commercial thinking. They seek to promote specific positive attitudes, values, practices or other business strategy programs. " [34]

Applying the principles of the circular economy is an ultimate purpose for the company. The company educates its employees to separate waste and recycle and also to apply these principles at home or pass it to other people. There are garbage bins for sorted waste on the company's premises.

As the owner of the company said: "Every year we try to improve the operation and be ever greener. This is also indicated by the annual cost optimization or efficiency of spending resources. Sanitary and common facilities are equipped with ecological faucets and sensor lights. So light and water are running only when needed. This year, the company even bought solar panels for the entire roof, covering a significant part of the electricity. " [34]

The company tries to recycle all possible input costs whenever possible, such as printer cartridges. It also renews its fleet to more environmentally friendly models. Sales 
representatives drive electric vehicles. However, it is more difficult with trucks that still run on fuel, and if there is a plan to buy a greener version of the trucks, the company would have to set aside a significant amount of money.

The company also provides a service for recycling end-user discarded products. Unfortunately, it is not a free service, as it is financially demanding with logistics, but $99 \%$ of customers take advantage of it. These are mostly products of large dimensions and high weight, where the disposal is complicated.

The application of the principles of the circular economy has brought a lot to the company. Although investments were initially higher, over time, negative figures in input costs were reached.

\section{Conclusion}

The need to introduce global aspects of CSR into the circular economy in business practice is essential to sustainable development. On a particular example from practice, we see that the introduction of such a form of business may not only have moral value, its application can be used through appropriate external communication to a more positive perception of the image of the company from the public perspective, i.e., potential customers, partners or new employees, which could also result in improved processes taking place in the company. However, when applying the principles of CSR and the circular economy to the company's processes, we should not forget the internal communication focused on our current employees. Correctly implemented internal communication will help us eliminate errors and lacks that may arise in the application; also, proper communication can generate new ideas and proposals with the streamline effect on the process, improve the business environment for employees, so the employees could perform their tasks and feel about leaving the lower carbon footprint during these activities, which can also have an impact on streamlining production processes.

This contribution is a partial result of the project VEGA 1/0078/18 Aspects of marketing communication in the management processes of the circular economy.

\section{References}

1. Czech, K. (2016). Europe 2020 targets as life quality measures in a global economy - an attempt of evaluation base on the example of Poland. In T. Kliestik (Ed.), Proceedings of the 16th International Scientific Conference on Globalization and its Socio-Economic Consequences (pp. 345-353). Rajecké Teplice, Slovakia.

2. Kot, S., Haque, A. U., \& Baloch, A. (2020). Supply chain management in smes: Global perspective. Montenegrin Journal of Economics, 16(1), 87-104.

3. Kot, S., Goldbach, I. R., Ślusarczyk, B. (2018). Supply chain management in SMEsPolish and Romanian approach. Economics \& Sociology, 11(4), 142-156.

4. Bilan, Y., Hussain, H. I., Haseeb, M., Kot, S. (2020). Sustainability and Economic Performance: Role of Organizational Learning and Innovation. Engineering Economics, 31(1), 93-103.

5. Musová, Z., Musa, H., Huliaková, Z. (2016). Innovative Approaches in a Socially Responsible Marketing in a Global Environment. In T. Kliestik (Ed.), Proceedings of the 16th International Scientific Conference on Globalization and its Socio-Economic Consequences (pp. 1466-1473). Rajecké Teplice, Slovakia. 
6. Nadanyiova, M., Gajanova, L., Majerova, J. (2020). Green Marketing as a Part of the Socially Responsible Brand's Communication from the Aspect of Generational Stratification. Sustainability, 12(17), 7118.

7. Shpak, N., Satalkina, L., Sroka, W., Hittmar, S. (2017). The social direction of enterprises' innovation activity. Polish Journal of Management Studies, 16(1), 187-201.

8. BASF (2020). Circular economy: A visionary roadmap? Retrieved from : https://www.basf.com/global/en/who-we-are/core-topics/creating-chemistrymagazine/resources-environment-and-climate/circular-economy.html

9. Ceniga, P., Šukalová, V. (2017). Green logistics as a part of corporate social responsibility in the process of globalization. In T. Kliestik (Ed.), Proceedings of the 17th International Scientific Conference on Globalization and its Socio-Economic Consequences (pp. 268-275). Rajecké Teplice, Slovakia.

10. Simo-Svrcek, S., Palus, H., Parobek, J., Supin, M. (2017). The importance of utilization of wood as a renewable material in the context of the green economy. In T. Kliestik (Ed.), Proceedings of the 17th International Scientific Conference on Globalization and its Socio-Economic Consequences (pp. 2377-2384). Rajecké Teplice, Slovakia.

11. Š́lková, D., Regnerová, M., Hes, A. (2015). Global extent of Food Waste. In T. Kliestik (Ed.), Proceedings of the 17th International Scientific Conference on Globalization and its Socio-Economic Consequences (pp. 627-634). Rajecké Teplice, Slovakia.

12. Zaušková, A., Grib, L. (2016). Impact of Globalization on Slovak Business in Marketing Promotion of Eco-innovations. In T. Kliestik (Ed.), Proceedings of the 16th International Scientific Conference on Globalization and its Socio-Economic Consequences (pp. 2465-2472). Rajecké Teplice, Slovakia.

13. Haseeb, M., Kot, S., Hussain, H. I., Kamarudin, F. (2020). The natural resources curseeconomic growth hypotheses: Quantile-on-Quantile evidence from top Asian economies. Journal of Cleaner Production, 279, 123596.

14. Michal, J., Sujová, A., Březina, D. (2018). The importance of products made of certified wood materials to consumers in the Czech Republic. Forum Scientiae Oeconomia, 6(3), 119-131.

15. Bussard, A., Marček, E., Markuš, M., Bunčák, M. (2005). Spoločensky zodpovedné podnikanie. Prehlad základných principov a príkladov. Retrieved from : https://www.nadaciapontis.sk/wpcontent/uploads/2019/01/text_zodpovedne_podnikanie.pdf

16. Stonkute, E., Vveinhardt, J., Sroka, W. (2018). Training the CSR Sensitive Mind-Set: The Integration of CSR into the Training of Business Administration Professionals. Sustainability, 10(3), 754.

17. The Economist (2009, November 17). Triple bottom line. The Economist. Retrieved from : https://www.economist.com/news/2009/11/17/triple-bottom-line

18. Zorkóciová, O., Baranova-Čiderova D., Pavelka, L., Škorvagova S. (2007). Corporate identity II. Bratislava: Vydavatel'stvo EKONÓM.

19. United Nations Global Compact. (2020). Who we are. United Nations Global Compact. Retrieved from : https://www.unglobalcompact.org/what-is-gc/our-work/

20. Stofkova, J., Gasova, K. and Rovnanova, A. (2016). E-government services for businesses in the globalized world. In T. Kliestik (Ed.), Proceedings of the 16th International Scientific Conference on Globalization and its Socio-Economic Consequences (pp. 2118-2126). Rajecké Teplice, Slovakia. 
21. Cséfalvayová, P. (2017). Slovensko a cirkulárna ekonomika. Inštitút cirkulárnej ekonomiky. Retrieved from : http://www.incien.sk/wpcontent/uploads/2017/05/CE_Brozura_2017.pdf

22. Oláh, J., Sadaf, R., Máté, D., Popp, J. (2018). The influence of the management success factors of logistics service providers on firms' competitiveness. Polish Journal of Management Studies, 17(1), 175-193.

23. Meyer, N., Meyer, D. F. (2016). The relationship between the creation of an enabling environment and economic development: A comparative analysis of management at local government sphere. Polish Journal of Management Studies, 14(2), 150-160.

24. Blazlak, R. New model of innovation and technology transfer. In T. Kliestik (Ed.), Proceedings of the 17th International Scientific Conference on Globalization and its Socio-Economic Consequences (pp. 170-178). Rajecké Teplice, Slovakia.

25. Kadlubek, M., Dziuba, S., Ingaldi, M. (2017). Idea of Sustainable development under conditions of globalization in the logistics management of the contemporary enterprise. In T. Kliestik (Ed.), Proceedings of the 17th International Scientific Conference on Globalization and its Socio-Economic Consequences (pp. 843-850). Rajecké Teplice, Slovakia.

26. Pietrzak, M., B., Balcerzak, A. (2016). Socio-economic sustainability in Poland. SEM analysis at the regional level. In T. Kliestik (Ed.), Proceedings of the 16th International Scientific Conference on Globalization and its Socio-Economic Consequences (pp. 1704-1711). Rajecké Teplice, Slovakia.

27. Haas, W., Krausmann, F., Wiedenhofer, D. (2020), Spaceship earth's odyssey to a circular economy - a century long perspective. Resources conservation and recycling, 163, 105076.

28. Figge, F., Thorpe, A. S., Good, J. (2021). Us before me: A group level approach to the circular economy. Ecological economics, 179, 106838.

29. Darnadyová, A. (2019). Kruhová ekomonika. Retrieved from : https://www.odpadyportal.sk/Dokument/102210/kruhova-ekonomika-circulareconomy.aspx

30. Matušínská, K., Stoklasa, M. (2019). The State of Strategic Marketing Application in Czech Small and Medium-Sized Enterprises. Scientific Annals of Economics and Business, 66(2), 193-212.

31. European Commission (2020). Internal Market, Industry, Entrepreneurship and SMEs. Retrieved from http://ec.europa.eu/enterprise/csr/campaign/documentation/download/guide_cs.pdf

32. Matulčíková, M., Srna, O. (2002). Krízový manažment. Bratislava: EKONÓM.

33. Stefko, R., Gavurova, B., \& Korony, S. (2016). Efficiency measurement in healthcare work management using Malmquist indices. Polish Journal of Management Studies, 13(1), 168-180.

34. Šalgovičová, J. (2019). Vybrané problémy marketingovej komunikácie v kruhovej ekonomike v etape globalizácie. Trnava: UCM v Trnave. 